\title{
Ecological Studies of the Macrobenthic Fauna of Ashtoum El-Gamil Protectorate, Port Said
}

\author{
Nagwa M. Elshenawy ${ }^{1}$; Nesreen K. Ibrahim² ${ }^{2}$ Gibreel M. Sharaf ${ }^{2}$ and \\ Saad. Z. Mohammed ${ }^{2}$ \\ 1- Ashtoum El-Gamil protectorate, Egyptian Environmental Affair Agency, Port- \\ Said, Egypt. \\ 2- Marine Science Department, Faculty of Science, Suez Canal University, \\ Ismailia, Egypt. \\ *Corresponding author: E-mail: nagwa_elshenawy@yahoo.com
}

\section{ABSTRACT}

Macrobenthic invertebrates samples were collected seasonally from five stations, selected according to their environmental ecosystem (marine, brackish and fresh) in Ashtoum El-Gamil protected area. This protectorate is located in the north western part of Lake Manzala. Macrobenthic community was found including thirty five species belonging to four groups. Of these species, 3 Polychaetes, 19 gastropods, 7 bivalves and 6 crustacean. Some of them are freshwater species and others are marine. Gastropods were dominated other groups, the highest average standing crop was recorded in station V. Macrobenthic fauna reached its maximum average value in spring in the whole area, while winter was the minimum productive season. Environmental parameter and nature of the sediment were important factors affecting distribution and abundance of macro benthic invertebrates. But It has been found that the percentage of the live organisms which have been monitored do not exceed $7 \%$ of total organisms.

Keyword: Macrobenthic Fauna, Ashtoum El-Gamil, Port Said.

\section{INTRODUCTION}

Manzala is located in the north east quadrant of the Delta, between (latitude $31^{\circ}$ $00^{`}-31^{\circ} 35^{`} \mathrm{~N}$ ) and (longitude $31^{\circ} 45^{\prime}$ and $32^{\circ} 15^{`} \mathrm{E}$ ). It is bounded by the Mediterranean Sea at the north, Suez Canal Lake at the east, Damietta province in the northwest and Dakahlia province in the southwest. The lake is $35 \mathrm{~km}$ long from northwest to southeast and $30 \mathrm{~km}$ wide, narrowing in the middle to only $15 \mathrm{~km}$ where the peninsula of Al-Shabul protrudes. Lake Manzala is a shallow Lake ranging from 0.7 to $1.5 \mathrm{~m}$ in depth, composed of about 30 basins varying in their depth and water quality. The deepest part $(3-5 \mathrm{~m})$ is in the location of old distributaries and along the Manzala navigation canal where regular dredging is taking over (Rashad and AbdelAzeem, 2010). Ashtoum El-Gamil and Tanis island protectorate was erected by ecision no. 459/1988 and modified by decision no. 2780/1998. It is located $13 \mathrm{~km}$ west of Port Said city covering an area of about $180 \mathrm{~km} 2$ laying completely inside Lake Manzala. Macrobenthos are those organisms which are retained on $0.5 \mathrm{~mm}$ screen (Wolff, 1983). The importance of benthos lies in its position asa secondary producer in the food chain and any change in benthos is reflected on the growth and production of fish. Macro invertebrate communities can be used as a good indicator for monitoring of ecosystem which can help in management and conservation of Lake Manzala (Fishar and Abdel-Gawad, 2009). 
The present work aims to study the physic-chemical parameters of Ashtoum ElGamil protectorate, the distribution and composition of macrobenthic fauna in relation to environmental parameters and heavy metals (in water and sediments) also, the seasonal changes and diversity of macrobenthos.

\section{MATERIALS AND METHODS}

\section{Sampling stations}

Samples were collected from five stations. Station I. Boughaz Ashtoum ElGamil $\left(31^{\circ} 16^{\prime} 03.34^{\prime \prime} \mathrm{N}\right.$ and $\left.32^{\circ} 10^{\prime} 10.65^{\prime \prime E}\right)$, station II. Boughaz El-Gamil $\left(31^{\circ} 17^{\prime} 09.85^{\prime \prime} \mathrm{N}\right.$ and $\left.32^{\circ} 12^{\prime} 57.66 " \mathrm{E}\right)$, station III. Bahr El-Kowr $\left(31^{\circ} 144^{\prime} 59.31 " \mathrm{~N}\right.$ and $\left.32^{\circ} 12^{\prime} 35.43^{\prime \prime E}\right)$, station IV. Bahr Tannis $\left(31^{\circ} 12^{\prime} 28.39^{\prime \prime} \mathrm{N}\right.$ and $\left.32^{\circ} 14 ' 50.67^{\prime \prime} \mathrm{E}\right)$ and station V. Bahr Ben El-Bareen (31 ${ }^{\circ} 18^{\prime} 58.05^{\prime \prime} \mathrm{N}$ and $\left.32^{\circ} 07^{\prime} 10.33 " \mathrm{E}\right)$, as illustrated in Figure 1.

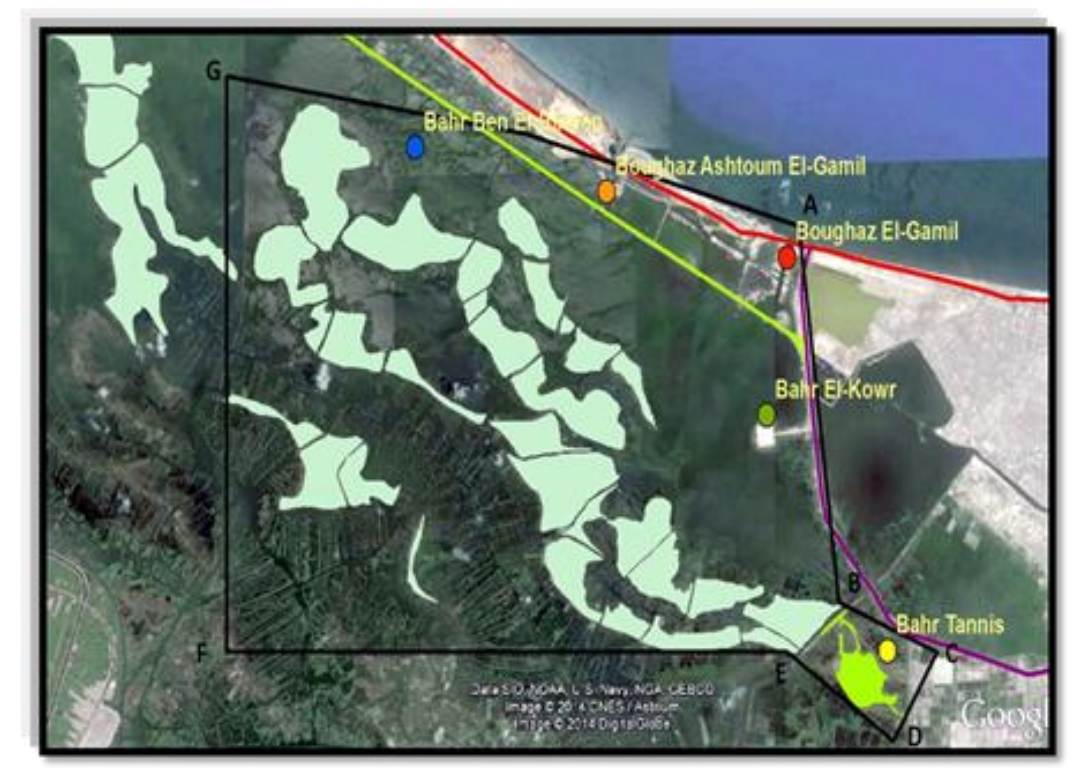

Fig. 1: Map showing sampling stations in Ashtoum El-Gamil protectorate

\section{Environmental parameters}

Temperature, $\mathrm{pH}$, dissolved oxygen, and salinity were measured seasonally in the field by using field thermometer, digital $\mathrm{pH}$ meter, Digital Dissolved Oxygen Meter (HI 98186)and refractrometer (ATAGO, Japan), respectively.

\section{Sediment analysis}

The sediment analysis was carried out according to the technique of Holme \& Mclntyre (1984), using an electric shaker and a set of sieves with meshes of (4mm, $2 \mathrm{~mm}, 1 \mathrm{~mm}, 500 \mu \mathrm{m} 250 \mu \mathrm{m}, 125 \mu \mathrm{m}$ and $63 \mu \mathrm{m}$ ). Organic matter, Nutrients and heavy metals in sediment and water were measured.

\section{Sampling and treatment of samples}

Benthic samples were collected seasonally from May 2012 to February 2013 using triangular dredge $(65 \times 65 \times 55 \mathrm{~cm})$ fitted with a bag net with mesh size of 3 $\mathrm{mm}$ to collect bottom fauna (figure7). The dredge was dragged for a distance of $10 \mathrm{~m}$ starting from the shore line. The samples were then preserved in the field with $10 \%$ buffered formalin solution. Three subsamples were taken from each sample and were examined under microscope and counted. Specimen of each species was preserved in $90 \%$ alcohol vials. The specimens were sorted to their main groups; each group was 
examined by stereo microscope and classified to its genera or species as far as possible, using available literature. The density of macro fauna was expressed as number of (individuals $/ \mathrm{m}^{2}$ ) in each site.

The PRIMER Ver. 5 statistical package was used for statistical analysis of data to measure Shannon-Wiener index (diversity H'), Margalef index (richness d) and Pielou's evenness index (J').

\section{RESULTS}

\section{Environmental parameters}

In the present study, water temperature reached its maximum in summer at station $\mathrm{V}\left(31.3^{\circ} \mathrm{C}\right)$ and decreased gradually until it reached its minimum in winter at stations II and III $\left(20.1^{\circ} \mathrm{C}\right)$. The water of study area lies at the alkaline side, the maximum value of $\mathrm{pH}(8.8)$ was recorded in station III\&V during winter, while the minimum one (7.5) was recorded in station IV during winter. The concentration of dissolved oxygen attained its maximum value $(17 \mathrm{mg} / \mathrm{l})$ in station II during winter, while the minimum $(3.6 \mathrm{mgll})$ was recorded in station IV during summer. It was found that the average value of dissolved oxygen reached its maximum in the whole area during winter. Salinity readings showed big differences among the stations in the area of investigation. Salinity varied from 1-34 ppt. The lowest average was recorded in autumn and winter while the highest one was in spring. On the other hand, it was found that stations IV and V showed the least recorded salinities.

\section{Sediment analysis}

Very fine sand $(125 \mu \mathrm{m})$ was dominant in three stations I, II and III whereas silt and clay $63 \mu \mathrm{m}$ and $40 \mu \mathrm{m}$ were dominant in station IV and V (Table 1).

Table 1: Grain size analysis of Ashtoum El-Gamil.

\begin{tabular}{|c|c|c|c|c|c|c|}
\hline Station & $\begin{array}{c}\text { Coarse Sand } \\
\% 1 \mathrm{~mm}\end{array}$ & $\begin{array}{c}\text { Medium Sand } \\
\% 500 \mu \mathrm{m}\end{array}$ & $\begin{array}{c}\text { Fine sand } \% \\
250 \mu \mathrm{m}\end{array}$ & $\begin{array}{c}\text { Very fine } \% \\
125 \mu \mathrm{m}\end{array}$ & $\begin{array}{c}\text { Silt } \% \\
63 \mu \mathrm{m}\end{array}$ & $\begin{array}{c}\text { Clay } \% \\
40 \mu \mathrm{m}\end{array}$ \\
\hline I & 10.27 & 2.68 & 4.75 & 64.30 & 9.79 & 8.21 \\
\hline II & 6.44 & 1.20 & 1.60 & 59.82 & 28.43 & 2.512 \\
\hline III & 3.93 & 1.33 & 5.15 & 87.37 & 1.51 & 0.71 \\
\hline IV & 0.12 & 5.9 & 8.13 & 14.59 & 23.97 & 47.22 \\
\hline V & 0.26 & 1.2 & 14.2 & 16.92 & 28.8 & 38.62 \\
\hline
\end{tabular}

\section{Organic matter and Nutrients}

The sediment total nitrogen values are attained the lowest value in station II $(45.36 \mathrm{mg} / \mathrm{g})$ and the maximum value in station IV $(94.5 \mathrm{mg} / \mathrm{g})$. Regarding to the total Phosphorus in different stations, it was found that Station IV attained the maximum value of total Phosphorus $(24.22 \mathrm{mg} / \mathrm{g})$ in all target stations while the minimum value was $3.76 \mathrm{mg} / \mathrm{g}$ (station II). Organic matter varied slightly in the study area from station to another (table 2).Organic matter ranged from 1 to $2.3 \%$ with the highest value in station IV (2.3\%) and the lowest value in station II (1\%).

\section{Heavy metals in water and sediment}

The concentrations of heavy metals $(\mathrm{Cd}, \mathrm{Cu}, \mathrm{Pb}, \mathrm{Mn}$ and $\mathrm{Zn})$ in water and sediment collected form Ashtoum El-Gamil protectorate during 2012-2013 are given in Table 2. Generally, it was observed that $\mathrm{Mn}$ attained the highest level and $\mathrm{Cd}$ recorded the lowest concentration level in both water and sediment. 
Table 2: Heavy metals concentrations in water and Sediment (mg/l) of Ashtoum El-Gamil.

\begin{tabular}{|c|c|c|c|c|c|c|c|c|c|c|}
\hline \multirow{2}{*}{ Stations } & \multicolumn{2}{|c|}{$\mathrm{Mn}$} & \multicolumn{2}{|c|}{$\mathrm{Zn}$} & \multicolumn{2}{|c|}{$\mathrm{Cu}$} & \multicolumn{2}{|c|}{$\mathrm{pb}$} & \multicolumn{2}{|c|}{$\mathrm{Cd}$} \\
\hline & water & Sediment & water & Sediment & water & Sediment & water & Sediment & water & Sediment \\
\hline St. I & 0.108 & 0.098 & 0.0063 & 0.0091 & 0.014 & 0.0068 & 0.0143 & 0.0208 & 0.00004 & 0.00013 \\
\hline St. II & 0.192 & 0.105 & 0.0211 & 0.0153 & 0.0126 & 0.007 & 0.0184 & 0.01103 & 0.0002 & 0.00009 \\
\hline St. III & 0.223 & 0.129 & 0.00407 & 0.0096 & 0.0046 & 0.0063 & 0.0019 & 0.0071 & 0.00008 & 0.00014 \\
\hline St. IV & 0.152 & 0.228 & 0.0112 & 0.0186 & 0.0072 & 0.01989 & 0.0212 & 0.03908 & 0.0007 & 0.00045 \\
\hline St. V & 0.188 & 0.21 & 0.0166 & 0.023 & 0.0193 & 0.0133 & 0.0156 & 0.0244 & 0.00012 & 0.00026 \\
\hline
\end{tabular}

\section{Species composition and abundance of macrobenthos}

In the present study, a total of 29 marine species and 6 fresh water species were recorded in the investigated stations of Ashtoum El-Gamil. In station 1, gastropods were found to be the most dominant group representing $44 \%$ of the total benthic organisms. Bivalves came next with a percentage occurrence of $30 \%$, then crustaceans contributed $24 \%$ and polychaetes with $2 \%$ of the total benthic organisms. At station II bivalves topped the list with a percentage incidence of $48 \%$ followed by gastropods with percentage of $32 \%$. Crustaceans were the next dominant group with $12 \%$ and polychaetes constituted $8 \%$ of the total macro benthic organisms. In station III, gastropods dominates with a percentage of $44 \%$ followed by crustaceans with $43 \%$ while, polychaetes with $10 \%$ and bivalves with $3 \%$. In station IV, gastropods outnumbered the other groups with a percentage $60 \%$, polychaetes were found to be the next dominant group with the percentage of $24 \%$ followed by bivalves $14 \%$ and crustacean with $2 \%$. As an oddity, in station $\mathrm{V}$, polychaetes emerged as dominant group with a percentage of $98 \%$ while bivalves and crustaceans are completely absent.

\section{Seasonal distribution}

Collectively, Population density in spring was 3-6 times those of other seasons revealing the flourishing of biota in this season. Concerning the studied stations, the population density was remarkably high at station $\mathrm{V}$ and particularly in spring followed in descending order by those in stations II, I, III and IV, respectively. Taxonomic group prevalence in all stations revealed the dominance of polychaets in spring $76 \%$ and winter $80 \%$. Summer and autumn showed the preference of bivalves and gastropods $45 \%$ and $39 \%$, respectively. The average density of total macrobenthic invertebrates during the study was 5316.1 organisms $/ \mathrm{m}^{2}$. Regarding to seasonal variation, density of total macrobenthos showed its maximum value in spring and summer (13212.8 and 3853.8 organisms $/ \mathrm{m}^{2}$, respectively) while its minimum value were recorded in winter 1988.4 organisms $/ \mathrm{m}^{2}$.

\section{Benthic diversity indices in the study stations}

The species richness, which identified as the total number of species in the studied stations, revealed that station II encounter the highest number of species (26) and Margalef index (2.5417) (Table 3). Station I and V recorded similar number of species (20) but with different index values. Maximum richness recorded in station II (2.5417) and minimum values recorded in station III (1.4614). The total number of individuals varied also among stations. The highest number recorded in station $\mathrm{V}$ (68649) (3-4 times those in station II which was 18697) and 10-12 times those of other stations. Maximum evenness recorded in station II (0.78239) and minimum values recorded in station $\mathrm{V}(0.2515)$. Shannon index recorded the minimum diversity value in station $\mathrm{V}(0.754)$ and the maximum was recorded in station II (2.5491). 
Table 3: Benthic diversity indices.

\begin{tabular}{|c|c|c|c|c|c|}
\hline Stations & $\begin{array}{c}\text { Total } \\
\text { Species }\end{array}$ & $\begin{array}{c}\text { Total } \\
\text { Individual }\end{array}$ & $\begin{array}{c}\text { Species richness } \\
\text { (Margalef index) }\end{array}$ & $\begin{array}{c}\text { Species Evenness } \\
\text { (Pielou's evenness index) }\end{array}$ & $\begin{array}{c}\text { Species diversity } \\
\text { (Shannon index) }\end{array}$ \\
\hline St. I & 20 & 7375 & 2.1334 & 0.72604 & 2.175 \\
\hline St. II & 26 & 18697 & 2.5417 & 0.78239 & 2.5491 \\
\hline St. III & 14 & 7288 & 1.4614 & 0.64911 & 1.713 \\
\hline St. IV & 17 & 4313 & 1.9117 & 0.74705 & 2.1166 \\
\hline St. V & 20 & 68649 & 1.706 & 0.2515 & 0.754 \\
\hline
\end{tabular}

\section{DISCUSSION}

Salinity is one of the most important factors that affect the species dynamics, faunal composition, distribution and diversity of bottom population in many aquatic ecosystems (Edgar \& Barrett, 2002). In the present study, the maximum value of salinity was recorded in spring and summer in st. I and st. II. This may be due to the discharge of Mediterranean Sea water. The minimum value of salinity was recorded at st I. and st. V during autumn and winter. This may be due to the effect of fresh water discharged from Bahr El-Baqr drain. Similar observation was recorded by (AbdelSatar, 2001 and Ali, 2008). The salinity values of the stations I and II varied from season to season. This is due to the increase invasion of freshwater into the lake from Bahr El-Baqr drain during the winter crops in the southern parts of the lake (tannis) (Donia \& Ahmed, 2006 and Rashad et al., 2012). The maximum value of dissolved oxygen was recorded at El-Gamil station during winter. This may be due to the decrease of water temperature which corresponding with the solubility of oxygen. Dissolved oxygen was in complete depletion at Tannis station during summer. This may be due to the presence of a high load of organic and inorganic pollutants discharged into Bahr El-Bakar drain which consumes dissolved oxygen during oxidation, nitrification and decomposition processes. These results were agreed with many authors (El-Enany, 2004; Abdel-Satar \& Geneid, 2009 and Abdel-Rasheed, 2011). PH values of Lake Manzala were fluctuated between 7.5 and 8.8 with significant variations and this result is agreed with (Ali, 2008). The lowest $\mathrm{pH}$ values were mostly recorded in the southern region in front of Bahr El-Baqr drain due to the fermentation of the organic matter and liberation of hydrogen sulphide and methane gases which lead to lowering $\mathrm{pH}$ values (Abdel-Satar, 2001 and Elewa \& Ghallab, 2000). Heavy metals are natural trace components of the aquatic environment, but their levels have increased due to industrial wastes, geochemical structure, agricultural and mining activities (Kalay \& Canli, 2000). The water heavy metal concentration in all selected station in Ashtoum El Gamil protectorate showed that the concentration of $\mathrm{Mn}$ showed the highest level in the target area whereas $\mathrm{Cd}$ recorded the lowest concentration level. This result agrees relatively with Bahnasawyet al., (2009) who recorded $\mathrm{Cd}$ as the lowest heavy metal concentration in Manzala Lake. Pb and $\mathrm{Cd}$ attained their maximum values at site IV which receives huge quantities about 1.5 million $\mathrm{m}^{3}$ of sewage and industrial wastes, beside agricultural drainage water via Bahr Al-Bakar drain (Badaway \& Wahaab, 1997 and Rashad et al., 2012) reported that water in Bahr Al-Bakar region is not suitable for human use. Soil texture plays an important role in the distribution and abundance of benthic fauna. Stations I, II and III had very fine sediment whereas in station IV and V, silt and clay were more dominat which agree with (Hamed \& Okbah, 2006 and Abdel Gawad et al., 2012). The organic matter in the sediments plays an important role in the accumulation and release of pollutants in the water, and it is a source of nutrients for the living fauna 
(Ahmed \& Elaa, 2003). The minimum value of organic matter was recorded at El-Gamil Station. This may be due to the high composition rate of organic matter in the presence of high dissolved oxygen content as mentioned by El-Wakeel \& Whaby (1970). The highest population density was observed in station V, this result due to presence of high amount of one species (Hydroid elegans). On the other hand, the highest value of live macrobenthic density in station II was because this station is the most ideal one in all parameter and the best location fed lake with marine water. While, the lowest population density value in station IV was due to the reception of huge quantities about 1.5 million $\mathrm{m}^{3}$ per day of sewage and industrial wastes, beside agricultural drainage water via Bahr Al-Bakar drain (Badaway \& Wahaab, 1997). The present study showed a marked seasonal variation in the species diversity, richness and evenness in all the stations. The minimum diversity value was recorded in station $\mathrm{V}$, and the maximum was recorded in station II. The variations in the species diversity observed in the present study could be deduced to the dynamic nature of the environments. Maximum richness recorded in station II and minimum values recorded in station III Maximum evenness recorded in station II and minimum values recorded in station this result due to large densities of (hydroid elegans). An increase in the percentage of organic matter in stations near to the sewage outlet cause decreases in oxygen and macrobenthic diversity (El-Sammak, 2001 and $\mathrm{Wu}, 2002)$ confirmed that in response to decreasing dissolved oxygen there are decreases in both species richness and diversity.

\section{REFERENCES}

Abdel Gawad, S. S.; Abdel-Hamid, A. M.; El-Barbary, M. I. and Mabrouk, A. M. (2012). Benthic invertebrate fauna in Ashtoum El Gamil protected area (Lake Manzalah), Egypt. Egypt. J. Aquat. Biol. \& Fish, 16 (4): 91-101.

Abdel-Rasheed, M. E. (2011). Ecological studies on Lake el-manzalah with special reference to their water quality and sediment productivity, ph. D. Thesis, Fac. Sci. Al-Azhar Univ., 367pp.

Abdel Satar, A. M. (2001). Environmental studies on the impact of the drains effluent upon the southern sector of Lake Manzala, Egypt, Egypt. J. Aquat. Biol. \& Fish. 5(3): 1730.

Abdel-Satar, A. M. and Geneid, Y. A. (2009). Evaluation of heavy metal status in Ecosystem of lake Manzalah, Egypt. J. Environ. Res., 3(3): 194-204.

Ahmed, M. H. and Elaa, A. A. (2003). Study of Molluscan shells and their enclosed bottom sediments in the Manzala lagoon, Nile delta, Egypt. Bull. Nat. Insti. Oceanog. Fish. A.R.E., 29: 427-450.

Ali, M. H. H. (2008). Assessment of some water quality characteristics and determination of some heavy metals in Lake Manzala, Egypt. Egypt. J. Aquat. Biol. \& Fish., 12(2): $133-154$.

Badawy, M. I. and Wahaab, R. A. (1997). Environmental impact of somechemical pollutants on Lake Manzala. International Journal of Environ. Health Rese., 7: 161-170.

Bahnasawy, M. H.; Khidr, A. A. and Dheina, N. A. (2009). Assessment of heavy metals concentrations in water, plankton and fish of Lake Manzala, Egypt. Egypt J. Aquat. Biol. \& Fish., 13(2): 117-133.

Donia, N. and Ahmed, M. H. (2006). Spatial investigation of the water quality in Lake Manzala is using Gis techniques. 1st Inter. Conf. on Envir. Change of Lakes, Lagoons and Wetlands of the Southern Mediterranean Region, 3-7 January, 06, Cairo, Egypt.

Edgar, G. J. and Barrett, N. S. (2002). Benthic macro fauna in Tasmanian estuaries Scale of distribution and relationship with environmental variables, J. Exp. Mar. Bio. Ecol., 270: 1-24. 
El-Enany, H. R. (2004). Ecological and biological studies on Lake El-Manzalah with special reference to their water quality and sediment productivity. M.Sc. Thesis, Fac. Sci., Al-Azhar University, pp.386.

Elewa, A. A. and Ghallab, M. H. (2000). Water-sediment interaction infront of El-Rahawv drain Rossetta branch, River Nile, Egypt. Presented at 41 international symposium on sediment quality assessment Otsu, Japan, October, 24-27.

El-Sammak, A. (2001). Heavy metal pollution in bottom sediment, Dubai, united Arab Emirates. Bull. Environ. Contam. Toxical, 26(2): 296-303.

El-Wakeel, S. K. and Wahby, S. D. (1970). Bottom sediments of Lake Manzalah, Egypt. Journal of Sedimentary Petrology, 40: 480-496.

Fishar, M. R. and Abdel Gawad, S. S. (2009). Macro invertebrate communities associated with the Macrophyte Potamogetonpectinatus L. in Lake Manzalah, Egypt. Global Veterinaria, 3(3): 239-247.

Hamed, M. A. and Okbah, M. A. (2006): Trace metals speciation in sediments of Lake Manzala, Egypt. Egypt J. Aquat. Biol \& Fish., 1(10): 3:137.

Holme, N. A. and Mclntyre, A. D. Eds (1984): Methods for the study of Marine Benthos, 2nd Ed Blackwell Oxford, 387 pp.

Kalay, M. and Canl1, M. (2000). Elimination of essential (Cu, $\mathrm{Zn})$ and non-essential $(\mathrm{Cd}, \mathrm{Pb})$ metals from tissues of a freshwater fish Tilapia zillii following an uptake Protocol. Turkish J. of Zool., 24:429-436.

Rashad, H. M. and Abdel-Azeem, A. M. (2010). Lake Manzala, Egypt: A bibliography. Assiut Univ. J. of Botany, 39(1): 253-289.

Rashad, H.; Mohamed; Abdel-Azeem, A. M. and Salem, F. M. (2012). Water Pollution and human health: Lake Manzala, Egypt: A Case study. Second International Conference of Physiological, Microbiological and Ecological Plant Sciences. El-Minia, April 2930, 2012. Abstract book: 31-32.

Wolff, W. J. (1983). Estuarine benthos. In: B-ostwick H. Ketchum (ed.), Ecosystems of the world 26. Estuarine and enclosed seas. Elsevier Science Publishers B.V., Amsterdam, the Netherlands, pp. 151-182.

Wu, R. S. S. (2002). Hypoxia: Form molecular responses to ecosystem responses. Marine Poll. Bull., 45(1-12): 35-45.

\section{ARABIC SUMMARY}

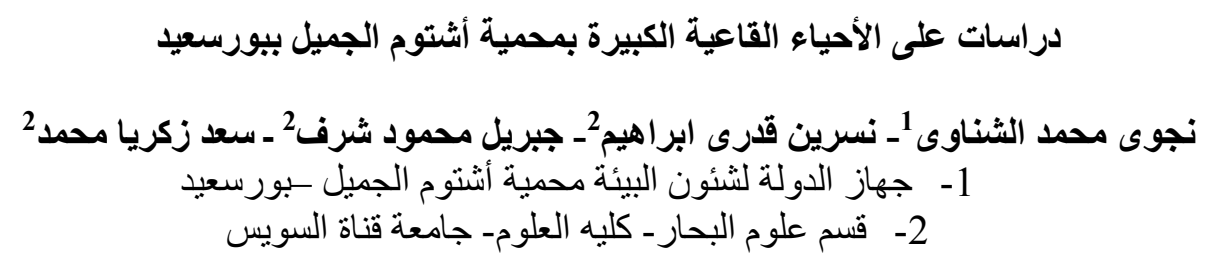

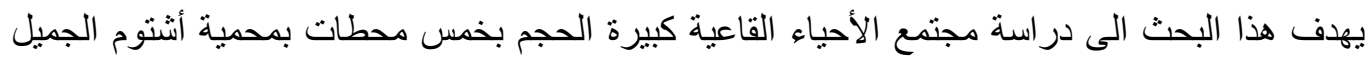

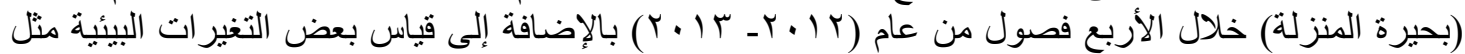

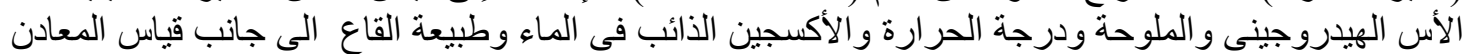

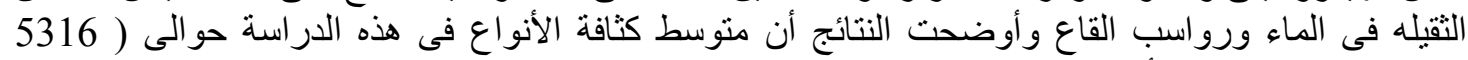

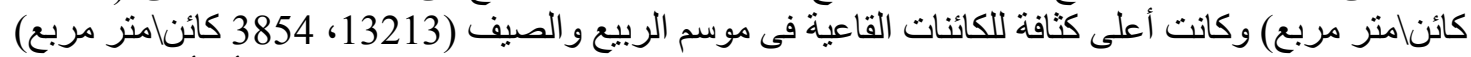

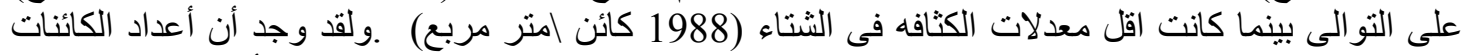

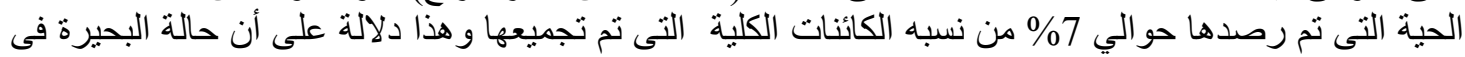

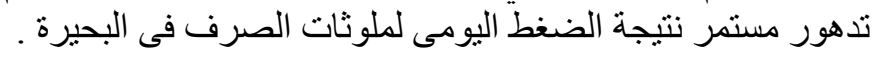

